\title{
Cow's milk consumption and risk of disease
}

\author{
Kaskous $\mathbf{S}^{*}$ \\ Department of Research and Development, Siliconform, Türkheim
}

\section{A B S T R A C T}

\begin{abstract}
Milk and dairy products are important components of the human diet. This has been true since the beginning of domestication of lactating animals. However, milk of any species is geared towards the growth and development of its own offspring. Thus, the role of milk and dairy products in human nutrition has been increasingly discussed in recent years. To the best of our knowledge, problems such as lactose intolerance, protein allergies and an increased risk of cancer can occur when consuming cow's milk. Around $70 \%$ of the world's total population is lactose intolerant, while $20 \%$ of adults in Europe are lactose intolerant. In the small intestine, lactose is hydrolytically split into glucose and galactose by the enzyme lactase located in the mucous membrane cells. After infancy, lactase activity decreases as the ability to synthesize lactase is lost. As a result, adults can no longer tolerate large amounts of lactose, and many develop diarrhea and uncomfortable painful symptoms such as gas, cramps, and a bloated stomach. Since lactase activity is limited in the case of hereditary lactose intolerance, people can easily tolerate milk without lactose. Another aspect is that between $2-5 \%$ of children are allergic to cow's milk. The allergy is less common in adulthood. Most allergic reactions affect the skin, gastrointestinal tract, and respiratory system, and severe anaphylaxis can occur. A therapeutic approach related to the causes of this multi-organ disease does not yet exist. A possible approach to reducing protein allergens is to block IgE-binding epitopes in patients. The most effective treatment is an elimination diet and the use of appropriate substitution formulas. Camel milk may replace cow's milk in the event of intolerance. Furthermore, many studies have showed that people with a higher cow's milk intake had slightly increased cancer and all-cause mortality rates. In conclusion, it has not been clarified what exactly constitutes the harmful or health-promoting effects of cow's milk. Cow's milk is so rich in ingredients that both effects are conceivable. Due to the central importance of milk and dairy products for human nutrition, there is still great scientific interest in expanding knowledge concerning the ingredients and their nutritional and physiological effects.
\end{abstract}

Keywords: Lactose intolerance; Protein allergies; Cancer; Cow's milk; Children

\section{INTRODUCTION}

Milk occupies a special position among foods, as it is the only food that nature produces specifically for the nutrition of humans and animals. The introduction of cow's milk into the diet has a very long tradition. Humans have been drinking cow's milk for around 9000 (McGee H., 2004) or 7500 years (www.quarks.de, 2020). This makes man the only living being that continues to consume milk after weaning - although from a different species. Milk is still an important supplier of calcium (Michaelsen et al., 2011; www. utopia.de, 2015) and is known for its calming properties. In addition, cow's milk is consumed by large numbers of the population and used in the manufacture of a wide variety of foods. Therefore, a diet without milk and dairy products is hard to conceive. However, the role of milk and milk products in human nutrition has been increasingly discussed in recent years (Boye et al., 2010; Hochwallner et al., 2014; www.quarks.de, 2020), as they constitute a major allergen for infants and children (Santoro et al., 2019). Patients with cow's milk allergy must therefore be able to identify foods containing milk and avoid them in their diets (Santoro et al., 2019). The less precise diagnosis of cow's milk protein allergy or lactose intolerance summarizes some clinical symptoms in humans that appear after consumption of cow's milk and disappear again when the milk intake is stopped. The main reasons for this are disorders in the digestion of milk proteins and milk sugar. Around $70 \%$ of the world's total population are lactose intolerant (www. utopia.de, 2015; www.quarks.de, 2020), whereas in Europe about 10\% (Krömker, 2007) or 30\% (www.quarks.de, 2020) of adults suffer from lactose intolerance.

From an allergological point of view, cow's milk is the first food that is most likely to cause allergies in infants and young children (Host, 2002). The reported prevalence of cow's milk allergy varies dramatically between studies, possibly due to different diagnostic methods or differences 
in the age of the populations studied (Venter and Arshad, 2011). In general, the incidence of self-reported side effects of cow's milk is much higher than that of confirmed diagnoses (Lack, 2008), not only in children but also in adults (Fiocchi et al., 2010). Scientists assume that between $2-5 \%$ of children in Europe are affected by a cow's milk allergy (Host and Halken, 2014; Lifschitz and Szajewska, 2015). After the hen's egg, cow's milk is the second most important food allergen in children. The allergy is less common in adults.

The aim of this overview study is to shed light on the risk factors after consuming cow's milk. Therefore, cow's milk protein allergy, lactose intolerance and cancer risk are described and discussed.

\section{ALLERGY TRIGGERED BY CONSUMPTION OF COW'S MILK}

Feeding babies with breast milk offers protection against allergic diseases. A foreign protein from cow's milk is partially absorbed in infants without being split, whereupon sensitization to the foreign protein can be triggered (Krömker, 2007). The first side effects of cow's milk were first described more than 2390 years ago by Hippocrates (Chabot, 1951; Host, 1997). About 500 years later a case of milk allergy was described by Galen (O'Keefe, 1953). At the beginning of the 20th century, observations of side effects of cow's milk were seen more frequently (Schlossmann and Moro, 1903; Finkelstein, 1905; Wernstedt, 1910). In 1938 allergic reaction due to inhalation of cow's milk protein was described in a Danish dairy worker (Hansen, 1938). Cow's milk allergy was considered an infrequent disease, but since the 1950s an increasing frequency has been noted (Hamburger, 1989; Hochwallner et al., 2014). Since the beginning of artificial infant feeding and its spread in almost the entire population, intolerance to cow's milk proteins has become a problem (Savilahti, 1981). It is estimated to affect around 1-5\% of babies under 1 year (Host, 2002; Venter et al., 2006; Eller et al., 2009). However, most children have outgrown it by the age of 3-5 years (Venter et al., 2008; Eller et al., 2009; www.nhs.uk, 2019). Fiocchi et al., (2010) reported that $0.6-2.5 \%$ of preschool children, $0.3 \%$ of older children and adolescents, and less than $0.5 \%$ of adults continued to suffer from cow's milk allergy. Another study found that the prognosis of cow's milk protein allergy is good with a remission rate of 45-50\% after 1 year, 60-75\% after 2 years and 85-90\% after 3 years (Host and Halken, 2014). Although the majority of infants outgrow a cow's milk allergy (Host et al., 2002; Martorell-Aragones et al., 2015), Some affected children remain allergic much longer, which can persist into adulthood (Skripak et al., 2007).

\section{BODY REACTION AFTER CONSUMPTION OF COW'S MILK IN ALLERGIC INFANTS AND CHILDREN}

A cow's milk allergy can cause different kinds of reactions, depending on the chemicals released, and the allergy is categorised on the basis of these causes:

- Immunoglobulin E (IgE)-mediated reactions against cow's milk allergy: The immune system releases histamine and other chemicals in response to cow's milk protein. The immediate and IgE-associated mechanisms are responsible for approximately $60 \%$ to $70 \%$ of the side effects, starting within $15-30 \mathrm{~min}$ after exposure to cow's milk protein, even in low amounts (Franceschini et al., 2018; Santoro et al., 2019). The majority have two or more symptoms from two or more organ systems. That means, $50-70 \%$ have cutaneous symptoms, $50-60 \%$ gastrointestinal symptoms and $20-30 \%$ respiratory symptoms (Host and Halkan, 2014), in some cases skin reactions, respiratory diseases and gastrointestinal reactions, and in some extreme cases even systemic anaphylaxis can be induced (Monaci et al., 2006; Fiocchi et al, 2010; Kattan et al., 2011). Typical IgE-associated symptoms appear immediately or within 1-2 hours after ingestion of cow's milk. Especially in infancy and childhood, cow's milk triggers complaints in the digestive tract or on the skin, often in connection with an atopic dermatitis attack (Sampson et al., 1998; www.utopia. de, 2015).

- Non-immunoglobulin E (IgE)-mediated reactions: In addition to IgE-associated mechanisms, non-IgE-mediated mechanisms of hypersensitivity to cow's milk also occur, but these are difficult to diagnose (Sampson, 1999). Symptoms that are not associated with $\operatorname{IgE}$ are characterized by a delayed onset of about 2 hours to several days after consumption of cow's milk. Patients suffering from this form of hypersensitivity insufficiency circulate cow's milk protein-unspecific IgE and show negative results in skin samples (Burks et al., 1990; Pelto et al., 1999; Ewing and Allen., 2005; Shek et al., 2005; Kattan et al., 2011). It is estimated that around $0.5 \%$ of all infants have non-IgE-mediated cow's milk allergy, whereas it seems to be more common in adults (Katz et al., 2010). T- Cells are thought to be the trigger for the symptoms, which appear more gradually, from 48 hours up to a week after consuming cow's milk protein (Bischoff and Sellge 2003).

- Mixed IgE and non-IgE reactions: This is a combination of immunoglobulin E-mediated reactions and non-immunoglobulin E-mediated reactions. It is also possible for patients to experience mixed 
manifestations caused by $\operatorname{IgE}$ and non-IgE mediated reactions. Both humoral and cell-mediated mechanisms can produce symptoms, including acute and chronic manifestations (Caffarelli et al., 2010; Hochwallner et al., 2014; Kansu et al., 2016).

\section{SYMPTOMS OF A COW'S MILK ALLERGY}

A cow's milk allergy can occasionally cause severe allergic symptoms that come on suddenly.

- Skin reactions: Itchiness, reddening of the skin, sudden itchy rash (urticarial - either in one spot or generally all over), or swelling, most often of the lips, face, and around the eyes. Sometimes the skin allergy turns into a topic eczema. Various studies have reported that between 33 and $81 \%$ of children with infantile eczema have IgE-mediated food allergy (Sampson, 1998; Eigenmann and Calza, 2000). Furthermore, a study of 2184 infants showed that the risk of egg, cow's milk, or peanut allergy was approximately twice as high if eczema was present in the first 6 months of life compared with the second 6 months of life (Hill et al., 2008).

- Gastrointestinal reactions: Swelling of the tongue or palate in the mouth, itching in the mouth, nausea, vomiting, colicky abdominal pain, blood in the stool, and failure to thrive or diarrhoea.

- Respiratory reactions: Itchy nose, sneezing, runny nose, congestion, cough, wheezing, or shortness of breath.

It is noteworthy that infants who have been fed cow's milk since birth can develop cow's milk protein intolerance within the first two to three months of life. Furthermore, various studies have reported that there is still no suitable therapy for cow's milk allergies other than avoidance. Therefore, research must focus on developing suitable and safe immunotherapies that do not cause serious side effects (Hochwallner et al., 2014).

\section{CAUSE OF COW'S MILK ALLERGY AND EXAMINATION OF WHICH MILK COMPONENTS ARE RESPONSIBLE FOR THE ALLERGY}

Since the factors that contribute to cow's milk allergy are not yet fully understood, it has been suggested that factors such as low levels of pepsin activity in the stomach at birth may be an immature mechanism for gastric acid production, and defective pancreatic and intestinal enzymes are responsible. Hence the gastric proteolysis could be limited and the risk of allergic reactions could be increase (Sakai et al., 2000).
Various mechanisms are discussed that lead to the initial sensitization to cow's milk proteins. One hypothesis is that sensitization can occur before birth: in this context, it has been shown that small amounts of dietary proteins consumed by pregnant women can reach the foetus via the placenta (Szepfalusi et al., 2000). In fact, it has been speculated that $\operatorname{IgE}$ is produced by foetuses in early pregnancy and can be detected in blood (Kamemura et al., 2012). The other possibility is sensitization soon after birth through intake of Cow's milk (Mastrorilli et al., 2020). However, it is still controversially discussed whether early contact with cow milk proteins leads to sensitization or to clinical tolerance to cow milk (Hochwallner et al., 2014). It is common knowledge that all infants should be breast-fed for the first six months, if possible (Saarinen et al. 1999; Host and Halken, 2004). It is noteworthy that sensitization to human milk has also been reported (Schulmeister et al., 2008). Clinical reactions usually begin very early in life after breastfeeding is stopped and cow's milk has been added to the diet, while symptoms rarely appear during breastfeeding (Schulmeister et al., 2008; Jarvinen and Suomalainen, 2001; Kattan et al., 2011).

In principle, several immunological mechanisms can be responsible for non-IgE-mediated reactions to cow's milk proteins (Bischoff and Sellge, 2003).

An allergy to cow's milk is due to different components (Wood et al., 2013; Martorell-Aragones et al., 2015). There are at least 40 individual protein components in cow's milk that can trigger antigenic reactions in humans (Table.1). As a rule, the cow's milk allergy does not consist of just one component, but most affected individuals have a sensitivity to both caseins and whey proteins (Bartuzi et al., 2017). Casein and $\beta$-lactoglobulin $(\beta$-Lg) have been classified as the main allergens, while bovine serum albumin (BSA), $\alpha$-lactalbumin $(\alpha-\mathrm{La})$, immunoglobulin (Ig) and lactoferrin (LF) are known to be minor allergens (Monaci et al., 2006). However, the $\beta-\mathrm{Lg}$ in cow's milk is responsible for most intolerances in infancy. The properties of these proteins are detailed as follows:

$\beta$-Lg: This protein makes up $57 \%$ of the total protein in the whey fraction of milk (Kaskous, 2020). There are seven genetic variants of $\beta-\mathrm{Lg}$ (A, B, C, D, E, F, G) (Kaskous, 2020). $\beta$ - $\mathrm{Lg}$ is relatively stable to denaturation and resistant to proteolytic hydrolysis by chymotrypsin and pepsin, but is susceptible to trypsin hydrolysis. (Maynard et al., 1998). Six IgG-binding regions and seven different IgE-binding epitopes have been identified that cause allergic reactions in humans (Selo et al., 1999; Jarvinen et al., 2001).

It is noteworthy that the bovine $\beta$ - $\mathrm{Lg}$, which is the main allergen in infancy and childhood, could not be detected 
Table 1: Compositional protein quality in cow's milk (Kaskous, 2020)

\begin{tabular}{|c|c|c|}
\hline Protein components & Protein subclasses & Concentrations $(\mathrm{g} / \mathrm{kg})$ \\
\hline \multirow[t]{5}{*}{ Caseins } & $\alpha_{s 1}$-casein $(A, B, C, D, E)$ & 10.3 \\
\hline & $\alpha_{\mathrm{s} 2}$-casein $(A, B, C, D)$ & 2.7 \\
\hline & $\beta$-casein (A1, A2, A3, B, C, D, E, F, G, $\left.\mathrm{H}^{1}, \mathrm{H}^{2}, \mathrm{I}\right)$ & 9.6 \\
\hline & k-casein $(A, B)$ & 3.5 \\
\hline & $\gamma$-casein & 0.8 \\
\hline \multirow[t]{7}{*}{ Whey Proteins } & $\alpha$-Lactalbumin (A, B, C) & 1.2 \\
\hline & $\beta$-Lactoglobulin (A, B, C, D, E, F, G) & 3.4 \\
\hline & Serum albumin & 0.4 \\
\hline & Immunoglobulins (A, G1, G2, M, E) & 0.7 \\
\hline & Lactoferrin & 0.1 \\
\hline & Transferrin & 0.1 \\
\hline & Other minor proteins & 0.1 \\
\hline Enzymes & $\begin{array}{l}\text { About } 60 \text { enzymes in five groups: oxidoreductases, transferases, hydrolases, } \\
\text { lyases and isomerases }\end{array}$ & traces \\
\hline Peptide Hormone & Prolactin, growth hormone, insulin growth factor (IGF) & traces \\
\hline Non-protein-nitrogen & $\begin{array}{l}\text { Urea, creatine, creatinine, peptide, uric acid, hippuric, orotic acid, free amino acids, } \\
\text { nucleic acids. }\end{array}$ & 1.1 \\
\hline
\end{tabular}

in camel milk (El-Agamy et al., 2009; Smits et al., 2011; Kaskous and Pfaffl, 2017). This is why camel milk can replace cow's milk in the event of intolerance. In camel milk, whey protein $\alpha$-La is the major whey milk component (Wernery, 2007; Al hag and Al Kanhal, 2010), whereas in cow's milk whey, $\beta$-Lg is the main component (57\%) and $\alpha$-La is the second (20\%) (Frister, 2007).

Casein: Caseins constitute about $80 \%$ of the total proteins of cow's milk (Kaskous, 2020). The casein protein fractions are $\alpha_{\mathrm{s} 1}$-casein $(30.3 \%), \alpha_{\mathrm{s} 2}$-casein $(7.9 \%), \beta$-casein $(28.2 \%)$, k-casein (10.3\%) and $\gamma$-Casein (2.4\%) (Jost, 1988; Wal, 1998a; Kaskous, 2020). It is believed that after consuming casein, most of the potentially antigenic or allergenic structures are modified under acidic gastric conditions by the action of digestive enzymes and absorption through the intestinal mucosa (Wal, 1998b). In milk allergic children with persistent symptoms, a significantly higher content of specific $\operatorname{IgE}$ antibodies against linear epitopes of $\alpha_{s 1}$-casein and $\beta$-casein was found than in children who had achieved tolerance (Vila et al., 2001).

It is also noted that if there is an allergy to casein, no other milk will be tolerated; even breast milk is not tolerated because it also contains casein. Since casein is not animalspecific, all types of milk must be avoided if there is a proven allergy to casein. However, in camel milk $\beta$-casein is the main fraction, followed by $\alpha_{\mathrm{s} 1}$-casein, $\alpha_{\mathrm{s} 2}$-casein and k-casein (El-Agamy, 2006; Hamed et al., 2012; Kaskous and Pfaffl, 2017). It is hypothesised that since $\beta$-casein is more sensitive to peptic hydrolysis than other fractions, the higher percentage of this casein fraction in camel milk as compared to bovine milk could reflect its higher rate of digestibility and lower the incidence of allergy in the infants nourished with camel milk (El-Agamy et al., 2009; Jadhav et al., 2019).
$\alpha$-La: This protein represents $25 \%$ of whey proteins. Various studies have confirmed the presence in $\alpha$-La of linear epitopes that are able to bind human $\operatorname{IgE}$ antibodies (Maynard et al., 1997; Jarvinen et al., 2001).

BSA: BSA makes up around $5 \%$ of total whey proteins. Antigenic epitopes on BSA that recognize human $\operatorname{IgE}$ antibodies and antibodies from mice have been identified (Beretta et al., 2001)

LF: LF is a milk-specific iron-binding protein representing less than $1 \%$ of total whey protein. However, to date, no studies have been conducted to identify LF IgE epitopes or T-cell epitopes.

IgG: The $\operatorname{IgG}$ fraction accounts for about $6 \%$ of whey proteins. Unfortunately, based on the available literature, there are no reports of $\mathrm{B}$ or $\mathrm{T}$ cell epitopes of bovine $\mathrm{IgG}$.

\section{INFLUENCE OF MILK PROCESSING ON THE ALLERGY-TRIGGER}

The 15 -minute heat treatment of milk at $90{ }^{\circ} \mathrm{C}$ reduced the immunoreactivity of $\alpha$-La and $\beta$-Lg compared to raw milk to $12.72 \%$ and $18.74 \%$ respectively (Wroblewska and Jedrychowski, 1994). Duranti et al. (1991) in previous studies also showed that the immunoreactivity of $\alpha$-La in sterilized milk decreased to $8 \%$ compared to raw milk. Severe heat treatment $\left(60\right.$ minutes at $\left.90^{\circ} \mathrm{C}\right)$ did not remove all IgE binding activity (Ehn et al., 2004). Moreover, Kleber et al. (2004) reported that heat-induced denaturation $\left(90^{\circ} \mathrm{C}\right)$ increased the allergenicity of $\beta$ - $\mathrm{Lg}$ by exposing previously hidden antigenic sites. It has been shown that up to $90 \%$ of $\beta$-Lg is aggregated in processed milk (Chen et al., 2005). 
Furthermore, some researchers observed that with heat treatment of the milk at temperatures above $100{ }^{\circ} \mathrm{C}, \alpha$-La, BSA and immunoglobulins are inactivated. Intolerance to these proteins no longer occurs after consuming UHT milk. However, the products resulting from the heat treatment of the milk can also create the new active fractions. These new active fractions are called the Maillard reaction after the chemist Louis Camille Maillard (Ledl and Schleicher, 1990; Schleicher 1991). Here amino acids and sugars are converted into new compounds under the influence of heat. The melanoidins formed by heating from sugars and amino acids are responsible for the intolerance. Since these occur primarily in UHT milk or sterile milk, these must then be avoided.

Duranti et al. (1991) suggested that heating and lactic acid fermentation might be more effective in reducing the immunoreactivity of some milk proteins. Similarly, Jedrychowski and Wroblewska (1999) and Maier et al. (2006) reported that sterilization of milk followed by lactic acid fermentation reduced the immunoreactivity of cow's milk proteins.

\section{TREATMENT OF COW'S MILK PROTEIN ALLERGY}

Infants at risk of cow's milk protein allergy can be identified by a family history of atopic disease. Exclusive breastfeeding for 4-6 months (17-27 weeks) is recommended as the best method of infant allergy prevention (Kansu et al., 2016; Mastrorilli et al., 2017), particularly if the infant is at high risk of developing milk allergy. However, the rate of cow's milk allergy in nursing infants is lower than in infants fed with formula and has been reported to be around 0.5\% (Host, 1994). It is noteworthy that there is no evidence that changing the mother's diet during pregnancy and/ or breastfeeding, and delaying solid or even potentially allergenic foods in infants beyond 4 to 6 months can protect against allergies in vulnerable infants (Kansu et al., 2016). If the child has a cow's milk allergy, then the mother should eliminate all foods containing cow's milk protein, including cheese, yogurt, and butter from her diet (Kansu et al., 2016). When exclusive breastfeeding is not possible, infants at risk of developing CMPA may benefit from a partially hydrolyzed formula to prevent allergies until a health professional has assessed their risk (Host and Halken, 2014). For infants with CMPA consuming formula, the first therapeutic option is exclusively the hydrolyzed formula as per guidelines. Other options are an amino acid-based formula or a rice-based formula. A partially hydrolyzed formula should not be used in infants with CMPA (Majamaa et al., 1996). Substitutes such as sheep and goat milk are generally not acceptable due to high cross-reactivity with cow's milk protein. However, research shows that there were fewer cross-reactions with camel milk (Restani et al., 1999). That is why camel milk can replace cow's milk in the event of intolerance (Kaskous and Pfaffl, 2017).

Soy proteins were the first recommended alternatives because of their hypoallergenicity, low cost, and convenience (Brady, 1986). However, the digestibility and nutritional quality of soy protein is affected by the presence of nutritional inhibiting factors such as trypsin inhibitors, phytic acid, and phenolic compounds (Boye et al., 2010). Researchers have reported that as many as $50 \%$ of children affected by cow's milk protein intolerance also develop soy protein intolerance if fed with soy-based formulas (Boyce et al., 2010; Koletzko et al., 2012). Reche et al. (2010) reported that the hydrolyzed rice protein formula was tolerated by more than $90 \%$ of children with cow's milk protein allergy and therefore could be a suitable and safe alternative to formulas hydrolyzed with cow's milk protein for these infants. New research has shown that treating cow's milk protein allergy with amino-acid formula appears to give better clinical results (high tolerance and less withdrawal due to taste or allergic reaction) (Berktas et al., 2020). In addition, recent evidence suggests that introducing complementary foods early (up to 6 months of age), including cow's milk, could prevent the development of food allergies. Several countries have included this new approach in their feeding guidelines (Mastrorilli et al., 2020). In the case of acute treatment, it must be mentioned that despite the best efforts of parents, medications like antihistamines can decrease the mild allergic reaction when a child accidentally consumes milk (Edwards and Younus, 2020). On the other hand, it was found that early barrier deficiency appears to promote the development of allergic sensitization, but does not appear to affect the acquisition of tolerance (Giannetti et al., 2019).

\section{MILK ALLERGENS IN FOOD}

Milk protein can be found in many foods that are not obviously related to milk - so consumers should pay attention to the labelling of the ingredients on food labels. According to the EU Consumer Information Regulation, milk and products made from it (including lactose) must be labelled and in the list of ingredients e.g., highlighted by font or background colour. This extended labelling requirement has been mandatory for packaged and unpackaged goods (open, loose goods) since December 2014.

\section{LACTOSE INTOLERANCE}

Lactose is the only dietary carbohydrate for babies in the first few months of life (Ingram et al., 2009) and its value 
as a carbohydrate and energy carrier appears to promote the absorption of $\mathrm{Ca}$ and other minerals such as phosphorus, magnesium, manganese and zinc (He, 2008; Michaelsen et al., 2011).

In the small intestine, lactose is hydrolytically split into glucose and galactose by the enzyme lactase located in the mucous membrane cells (Krömker, 2007). Only glucose and galactose can be absorbed into the blood through the intestinal mucosa. The activity of lactase is normally down-regulated after weaning (Krütli et al., 2014). This means, that most of human adults cannot digest lactose or can no longer digest it completely (lactose malabsorption) (Itan et al., 2010). This problem is found in around $65-70 \%$ of the adult population of Africa and Asia (Ingram et al., 2009; www.utopia.de, 2015; Bayless et al., 2017), while only around $15-20 \%$ of adult Caucasians have this syndrome (www.utopia.de, 2015). However, the continued production of lactase throughout adult life is a genetic trait and is found in Europe, especially Northern Europe (Leonardi et al., 2012), but also in regions of Central Africa, the Middle East and Asia (Krüttli et al., 2014) (Fig. 1).

A total of seven different genetic lactase polymorphisms have established themselves, which result in high lactase activity even in adulthood (lactase persistence) (Itan et al., 2010; Leonardi et al., 2012; Krüttli et al., 2014). Furthermore, various studies have reported that lactase persistence is the mutation, believed to be the result of strong positive selection that is only common in populations with a long history of pastoralism and milking. Scientists have determined the prevalence of lactose malabsorption or lactase non-persistence in many countries in the world, and the results have been presented below (Table 2).

If undigested lactose gets into the large intestine due to insufficient cleavage in the small intestine, it is used by the bacteria there and gaseous metabolic products such as hydrogen or methane are created (Report, 2014). Together with the osmotically induced water influx, these can cause flatulence, diarrhea and abdominal pain (lactose intolerance). Around $80 \%$ of colon bacteria have lactase activity, so they can break down lactose. Whether the fermentation of the lactose that entered the colon is causing symptoms is likely to depend on a number of factors. These include: (1) the composition of the intestinal microbiota and their metabolic activity; (2) the capacity of the intestine to absorb the fermentation products through the intestinal wall and thus remove them from the intestine; (3) the intestinal sensitivity (Leonardi et al., 2012; Venema, 2012). Bayless et al. (2017)

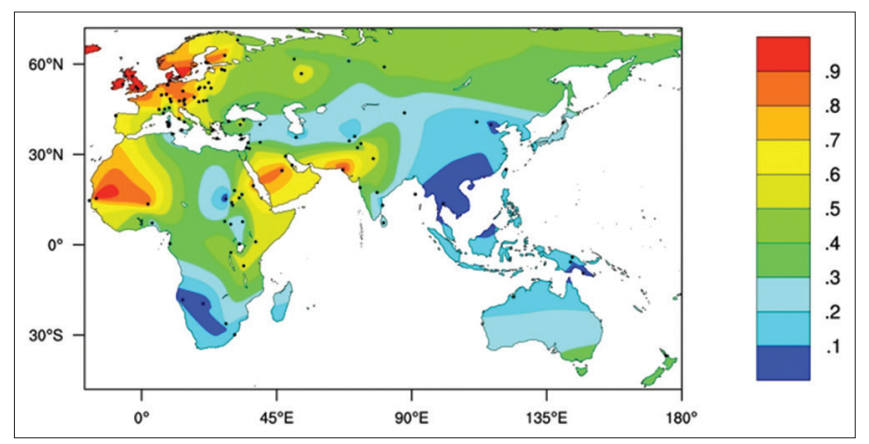

Fig 1. Map of old-world Lactase Persistence phenotype frequencies. Colors and color key show the frequencies of the lactase persistence phenotype estimated from surfaces. Number 9 is the highest frequency of lactase persistence and number 1 is the lowest frequency of lactase persistence according to Itan et al., (2010).

Table 2: Prevalence of lactase non-persistence (LNP) or lactose malabsorption (LM)

\begin{tabular}{lcll}
\hline The Countries & $\%$ & The Countries & $\%$ \\
\hline China (LNP) & 100 & Egypt (LM) & 73 \\
Vietnam (LM) & 100 & Germany (LM) & 70 \\
Japan (LM) & 100 & Hungary (LM) & 56 \\
Uganda, Bantu (LM) & 100 & Mexico (LM) & 53 \\
Peru, non-Caucasian (LM) & 94 & Northern Italy (LM) & 52 \\
Iraqi Jews (LNP) & 93 & Fulani (LNP) & 50 \\
Australian Aborigine (LM) & 84 & Greece (LM) & 45 \\
Nigerian Yorba (LM) & 83 & UK White (LNP) & 22 \\
Ashkenazi Jews (LNP) & 83 & Finland (LM) & 17 \\
Moroccan Jews (LNP) & 82 & USA White (LM) & 15 \\
USA Native American (LM) & 81 & Central Italy (LM) & 15 \\
Brazil (LM) & 80 & Ireland (LNP) & 14 \\
Chile (LM) & 80 & Denmark (LNP) & 12 \\
American African (LM) & 75 & Sweden (LNP) & 10 \\
\hline
\end{tabular}

(Swallow, 2003; Ingram et al., 2009; Raz et al., 2013; Paige, 2013; Bayless et al., 2017)

reported that the symptoms of lactose malabsorption are influenced by many factors.

In order to avoid symptoms of lactose intolerance without giving up milk and/or dairy products, there are a number of options that are detailed in various publications (Vesa et al., 2000; Venema, 2012; Brown-Esters et al., 2012). It is also noted that some lactose intolerant people who do not have irritable bowel syndrome at the same time can have a glass of milk with a meal with no or minor symptoms (Bayless et al., 2017). Therefore, people can easily tolerate up to $300 \mathrm{ml}$ of milk per meal, in which the lactase activity is limited in the case of hereditary lactose intolerance. Furthermore, lactase non-persistence and lactose intolerance are considered factors in global milk drinking habits (Szilagyi, 2015). Therefore, it was found that inhabitants of countries with a high prevalence of LNP consume less dairy products and conversely, in countries that have no problems digesting lactose, consume a lot of milk (Fig.1) (Shrier et al., 2008). 


\section{COW'S MILK AND CANCER RISK}

In recent years there has been intense discussion about whether the consumption of cow's milk could increase the risk of cancer (www.utopia.de, 2015). The answer is that, it depends on the type of cancer. Milk has a certain growth factor "Insulin-like Growth Factor-1". (IGF-1) that makes people grow taller. However, more cells and more frequent cell division mean a higher risk of cancer (Friebe, 2019). An epidemiological study has shown that taller people (growth promoted by milk) have an increased risk of bone fractures-but only in women (www.quarks. de, 2020). In the case of prostate cancer, there seems to be a stronger connection, so that frequent and heavy consumption of milk (over 1.25 litters/day) increases the risk of prostate cancer significantly (Friebe, 2019; www.quarks.de, 2020). Various mechanisms have been proposed by which the consumption of milk and/or dairy products can influence the development of prostate cancer. These include: 1) calcium suppresses the production of calcitriol (1,25-dihydroxy-Vitamin $\left.\mathrm{D}_{3}\right)$, which increases cell proliferation in the prostate; 2 ) consuming milk increases IGF-1 blood levels, which can lead to cell proliferation; 3) fat and saturated fatty acids (SFA) can be risk factors for prostate cancer (Stanton et al., 2013); 4) Branched-chain fatty acid metabolites can be carcinogenic (Ran-Ressler et al., 2014); and 5) the presence of oestrogens, which can be carcinogenic. These and the possible roles of fat and SFA have been studied in depth by Parodi (2009). The most important factor of the mentioned causes of prostate cancer seems to be an increased calcium intake from milk. Therefore, men do not have to get increased calcium from milk, as the risk of prostate cancer increases the more milk they consume (Song et al., 2013; www.quarks. de, 2020). Regarding the relationship between cow's milk intake and gastrointestinal cancer, it has been reported that the consumption of dairy products reduces the risk of gastrointestinal cancer (Park et al., 2009). Several metaanalyses of dairy products have shown protective effects against colon cancer (Cho et al., 2004; Aune et al., 2012). It is believed that the main protective factor is calcium (Muehlhoff et al., 2013), which inhibits the proliferation of aberrant crypt foci in the colon (Szilagyi, 2015). Studies with calcium intake have shown that high-dose calcium is necessary to protect against colon cancer and polyps (Weingarten et al., 2008). It is known that milk and dairy products contain high amounts of calcium. However, in western countries it is believed that adding vitamin $\mathrm{D}$ to milk also protects against colon cancer (Chandler et al., 2015; Bostick, 2015), but vitamin D is generally less likely to be added in Africa, Asia and the Middle East due to the abundance of sunshine there. Furthermore, a meta-analysis has shown that the consumption of dairy products reduces the risk of gastric cancer, as milk has a neutral effect (Guo et al., 2015). Hence, both women and men are advised that regular consumption of milk and dairy products can help prevent colon cancer. Conversely, it has been shown that dairy products may increase risk of breast cancer, through the following aspects; 1) high intake of dairy products that are high in saturated fatty acids; 2) dairy products can contain pesticides that can be carcinogenic; and 3) milk can contain growth factors, including IGF-1, that can promote the growth of breast cancer cells (Moorman and Terry, 2004). However, some ingredients in milk and dairy products such as calcium, vitamin $\mathrm{D}$, unsaturated fatty acids, and whey protein can protect against breast cancer (Moorman and Terry, 2004; Parodi, 2005). In general, a reduced consumption of animal foods is recommended for adults.

\section{CONCLUSION}

- A milk allergy is an abnormal reaction by the body's immune system to milk and dairy products. It is one of the most common food allergies in children. Cow's milk is the most common cause of milk allergies, but milk from sheep, goats and buffalo can also cause a reaction. Camel milk is an exception as it contains different protein components. This is why camel milk can be used to treat food allergies.

- It is known that about $70 \%$ of the world's adult population suffer from hypolactasia after childhood. Milk consumption is lower in countries with a high prevalence of lactase non-persistence than in countries with lactase persistence. The three phenotypes lactase persistence, lactase non-persistence and heterozygotes are under genetic control. Our recommendation for people with non-persistent lactase is to consume adequate amounts of calcium and vitamin $\mathrm{D}$, either from dairy products with reduced lactose content or as a supplement of calcium and vitamin $\mathrm{D}$.

- Research on cow's milk and cancer risk suggests dairy products should be consumed for development and bone health. As described, dairy products can be beneficial for certain diseases (e.g., colon cancer). High intake of dairy products in older men is not recommended. However, for other diseases, more studies are needed to better define the risks.

\section{REFERENCES}

Aune, D., R. Lau, D. S. Chan, R. Vieira, D. C. Greenwood, E. Kampman and T. Norat. 2012. Dairy products and colorectal cancer risk: A systematic review and meta-analysis of cohort studies. Ann. Oncol. 23: 37-45.

Bartuzi, Z., R. R. Cocco, A. Muraro and A. Nowak-Węgrzyn. 2017. Contribution of molecular allergen analysis in diagnosis of milk 
allergy. Curr. Allergy Asthma Rep. 17: 46.

Bayless, T. M., E. Brown and D. M. Paige. 2017. Lactase nonpersistence and lactose intolerance. Curr. Gastroenterol. Rep. 19: 23.

Beretta, B., A. Conti, A. Fiocchi, A. Gaiaschi, C. L. Galli, M. G. Giuffrida, C. Ballabio and P. Restani. 2001. Antigenic determinants of bovine serum albumin. Int. Arch. Allergy Immunol. 26: 188-195.

Berktas, M., F. Kirbiyik, E. Aribal, A. Aksit and D. U. Altintas. 2020. Treatment options for cow's milk protein allergy: A modelling analysis. Clinicoecon Outcomes Res. 12: 307-315.

Bischoff, S. C. and G. Sellge. 2003. Immune mechanisms in foodinduced disease In: D. D. Metcalfe, H. A. Sampson and R. A. Simon (Eds.), Food Allergy: Adverse Reactions to Food and Food Additives. $3^{\text {rd }}$ ed. Blackwell Science, Hoboken, New Jersey, pp. 14-37.

Bostick, R. M. 2015. Effects of supplemental Vitamin D and calcium on normal colon tissue and circulating biomarkers of risk for colorectal neoplasms. J. Steroid Biochem. Mol. Biol. 148: 86-95.

Boyce, J. A., A. Assa'ad, A. W. Burks, S. M. Jones, H. A. Sampson, R. A. Wood, M. Plaut, S. F. Cooper, M. J. Fenton, S. H. Arshad, S. L. Bahna, L. A. Beck, C. Byrd-Bredbenner, C. A. Camargo, L. Eichenfield, G. T. Furuta, J. M. Hanifin, C. Jones, M. Kraft, B. D. Levy, P. Lieberman, S. Luccioli, K. M. McCall, L. C. Schneider, R. A. Simon, F. E. Simons, S. J. Teach, B. P. Yawn and J. M. Schwaninger. 2010. NIAID-sponsored expert panel. Guidelines for the diagnosis and management of food allergy in the United States: Summary of the NIAID-sponsored expert panel report. J Allergy Clin. Immunol. 126: 1105-1118.

Boye, J. I., S. H. Rajamohamed and M. Britten. 2010. Processing foods free from dairy proteins. In: Boye and S. B. Godefroy (Eds), Allergen Management in the Food Industry. John Wiley and Sons, Edition Publication, Hoboken, New Jersey, pp. 207-258.

Brady, M. S., K. A. Rickard, J. F. Fitzgerald and J. A. Lemons. 1986. Specialized formulas and feedings for infants with malabsorption or formula intolerance. J Am Dietetic Assoc. 86:191-200.

Brown-Esters, O., P. Mc Namara and D. A. Savaiano. 2012. Dietary and biological factors influencing lactose intolerance. Int. Dairy J. 22: 98-103.

Burks, A. W., L. W. Williams, H. B. Casteel, S. C. Fiedorek and C. A. Connaughton 1990. Antibody response to milk proteins in patients with milk-protein intolerance documented by challenge. J. Allergy Clin. Immunol. 85: 921-927.

Caffarelli, C., F. Baldi, B. Bendandi, L. Calzone, M. Marani and P. Pasquinelli. 2010. Cow's milk protein allergy in children: $A$ practical guide. Ital. J. Pediatr. 36: 1-7.

Chabot, R. 1951. Pediatric Allergy. MacGraw-Hill, New York.

Chandler, P. D., J. E. Buring, J. E. Manson, E. L. Giovannucci, M. V. Moorthy, S. Zhang, I. M. Lee and J. H. Lin. 2015. Circulating Vitamin D levels and risk of colorectal cancer in women. Cancer Prevent. Res. 8: 675-682.

Chen, W. L., M. T. Hwang, C. Y. Liau, J. C. Ho, K. C. Hong and S. J. Mao. 2005. Beta-lactoglobulin is a thermal marker in processed milk as studied by electrophoresis and circular dichroic spectra. J. Dairy Sci. 88: 1618-1630.

Cho, E., S. A. Smith-Warner, D. Spiegelman, W. L. Beeson, P. A. van den Brandt, G. A. Colditz, A. R. Folsom, G. E. Fraser, J. L. Freudenheim, E. Giovannucci, R. A. Goldbohm, S. Graham, A. B. Miller, P. Pietinen, J. D. Potter, T. E. Rohan, P. Terry, P. Toniolo, M. J. Virtanen, W. C. Willett, A. Wolk, K. Wu, S. S. Yaun, A. Zeleniuch-Jacquotte and D. J. Hunter. 2004. Dairy foods, calcium, and colorectal cancer: A pooled analysis of 10 cohort studies. J. Natl. Cancer Inst. 96: 1015-1022.
Duranti, M., A. Carpen, S. lametti and S. Pagani. 1991. a-Lactalbumin detection in heat-treated milks by competitive ELISA. Milchwissenschaft. 46: 230-232.

Edwards, C. W. and M. A. Younus. 2020. Cow Milk Allergy. Available from: http://www.ncbi.nlm.nin.gov/books/ NBK542243.

Ehn, B. M., B. Ekstrand, U. Bengtsson and S. Ahlstedt. 2004. Modification of IgE binding during heat processing of the cow's milk allergen a-lactoglobulin. J. Agric. Food Chem. 52: 13981403.

Eigenmann, P. A. and A. M. Calza. 2000. Diagnosis of IgE-mediated food allergy among Swiss children with atopic dermatitis. Pediatr. Allergy Immunol. 11: 95-100.

El-Agamy, E. I. 2006. Camel milk. In: Park and F. W. Haenlein, (Eds.), Handbook of Non-Bovine Mammals. Blackwell Publisher Professional, lowa, NJ, USA, pp. 297-344.

El-Agamy, E. I., M. Nawar, S. M. Shamsia, S. Awad and G. F. W. Haenlein. 2009. Are camel milk proteins convenient to the nutrition of cow milk allergy children? Small Rumin. Res. 82: 1-6.

Eller, E., H. F. Kjaer, A. Host, K. E. Andersen and C. Bindslev-Jensen. 2009. Food allergy and food sensitization in early childhood: Results from the DARC cohort. Allergy. 64: 1023-1029.

Ewing, W. M. and P. J. Allen. 2005. The diagnosis and management of cow milk protein intolerance in the primary care setting. Pediatr. Nurs. 31: 486-493.

Finkelstein, H. 1905. Monatsschrift Kinderheilkunde. Vol. 4. pp. 6572.

Fiocchi, A., H. J. Schünemann, J. Brozek, P. Restani, K. Beyer, R. Troncone, A. Martelli, L. Terracciano, S. L. Bahna, F. Rance, M. Ebisawa, R. G. Heine, A. Assaad, H. Sampson, E. Verduci, G. R. Bouygue, C. Baena-Cagnani, W. Canonica and R. F. Lockey. 2010. Diagnosis and rationale for action against cow's milk allergy (DRACMA): A summary report. J. Allergy Clin. Immunol. 126: 1119-1128.e12.

Franceschini, F., P. Bottau, S. Caimmi, F. Cardinale, G. Crisafulli, L. Liotti, G. Pellegrini, D. Peroni, F. Saretta, C. Mastrorilli and C. Caffarelli. 2018. Evaluatind with suspected allergic reactions to vaccines for infectious diseases. Allergy Asthma Proc. 39: 177183.

Friebe, R. 2019. Gesundheits-Debatte: Ist Milch nun Gesund Oder Ungesund? Available from: http://www.tagesspiegel.de.

Frister, H. 2007. Zusammensetzung der milch. In: V. Krömker (Eds.), Kurzes Lehrbuch Milchkunde und Milch Hygiene. MVS Medizinverlage Stuttgart GmbH, Parey, pp. 80-101.

Giannetti, A., F. Cipriani, V. Indio, M. Gallucci, C. Caffarelli and G. Ricci. 2019. Influence of atopic dermatitis on cow's milk allergy in children. Medicina (Kaunas), 55: 460.

Guo, Y., Z. Shan, H. Ren and W. Chen. 2015. Dairy consumption and gastric cancer risk: A meta-analysis of epidemiological studies. Nutrition and Cancer, 67: 555-568.

Hamburger, R. N. 1989. Introduction: A brief history of food allergy with definitions of terminology in food intolerance. In: R. N Hamburger (Ed.), Food Intolerance in Infancy. Raven Pres, New York, pp. 1-6.

Hamed, H., A. J. Trujillo, B. Juan, B. Guamis, A. Elfeki and A. Gargouri. 2012. Interrelationships between somatic cell counts, lactation stage and lactation number and their influence on plasmin activity and protein fraction distribution in dromedary (Camelus dromedaries) and cow milk. Small Rumin. Res. 105: 300-307.

Hansen, P. 1938. Urticarial provoked by inhalation of milk protein (in Danish). Ugeskr Laeger. 100: 226.

He, T., K. Venema, M. G. Priebe, G. W. Welling, R. J. M. Brummer and R. J. Vonk. 2008. The role of colonic metabolism in lactose 
intolerance. Eur. J. Clin. Invest. 38: 541-547.

Hill, D. J., C. S. Hosking, F. M. de Benedictis, A. P. Oranje, T. L. Diepge and V. Bauchau. 2008. Confirmation of the association between high levels of immunoglobulin $E$ food sensitization and eczema in infancy: An international study. Clin. Exp. Allergy. 38: 161-168.

Hochwallner, H., U. Schulmeister, I. Swoboda, S. Spitzauer and R. Valenta. 2014. Cow's milk allergy: From allergens to new forms of diagnosis, therapy and prevention. Methods. 66: 22-33.

Host, A. 1994. Cow's milk protein allergy and intolerance in infancy. Some clinical, epidemiological and immunological aspects. Pediatr. Allergy Immunol. 5: 1-36.

Host, A. 1997. Cow's milk allergy. J. R. Soc. Med. 90: 34-39.

Host, A. 2002. Frequency of cow's milk allergy in childhood. Ann. Allergy Asthma Immunol. 89: 33-37.

Host, A. and S. Halken. 2004. Hypoallergenic formulas when, to whom and how long: After more than 15 years we know the right indication. Allergy. 59: 45-52.

Host, A. and S. Halken. 2014. Cow's milk allergy: Where have we come from and where are we going? Endocr. Metab. Immun. Disord. Drug Targets. 14: 208.

Host, A., S. Halken, H. P. Jacobsen, A. E. Christensen, A. M. Herskind and K. Plesner. 2002. Clinical course of cow's milk protein allergy/intolerance and atopic diseases in childhood. Pediatr. Allergy Immunol. 13: 23-28.

Ingram, C.J., C. A. Mulcare, Y. Itan, M. G. Thomas and D. M. Swallow. 2009. Lactose digestion and the evolutionary genetics of lactase persistence. Hum. Genet. 124: 579-591.

Itan, Y., B. L. Jones, C. J. E. Ingram, D. M. Swallow and M. G. Thomas. 2010. A worldwide correlation of lactase persistence phenotype and genotypes. BMC Evol. Biol. 10: 36.

Jadhav, S. A., U. D. Umrikar, M. P. Sawane, V. D. Pawar, R. S. Deshmukh, S. S. Dahiya and S. C. Mehta. 2019. Analysis of beta casein gene polymorphism in Indian camel breeds. J. Camel Pract. Res. 26: 245-249.

Jarvinen, K. M., K. Beyer, L. Vila, P. Chatchatee, P. J. Busse and H. A. Sampson. 2002. B-cell epitopes as a screening instrument for persistent cow's milk allergy. J. Allergy Clin. Immunol. 110: 293-297.

Jarvinen, K. M., P. Chatchatee, L. Bardina, K. Beyer and H. A. Sampson. 2001. IgE and IgG binding epitopes on alphalactalbumin and beta-lactoglobulin in cow's milk allergy. Int. Arch. Allergy Immunol. 126: 111-118.

Jedrychowski, L. and B. Wroblewska. 1999. Reduction of the antigenity of whey proteins by lactic acid fermentation. Food Agric. Immunol. 11: 91-99.

Jost, R. 1988. Physicochemical treatment of food allergens: Application to cow's milk proteins. Nestle Nutr. Workshop Ser. 17: 187-197.

Kamemura, N., H. Tada, N. Shimojo, Y. Morita, Y. Kohno, T. Ichioka, K. Suzuki, K. Kubota, M. Hiyoshi and H. Kido. 2012. Intrauterine sensitization of allergen-specific IgE analysed by a highly sensitive new allergen microarray. J. Allergy Clin. Immunol. 130: 113-121.

Kansu, A., A. Yüce, B. Dalgıc, B. E. Sekerel, F. Cullu-Cokugras and H. Cokugras. 2016. Consensus statement on diagnosis, treatment and follow-up of cow's milk protein allergy among infants and children in Turkey. Turk. J. Pediatr. 58: 1-11.

Kaskous, S. 2020. A1-A2-milk and their effect on human health. J. Food Eng. Technol. 9: 15-21.

Kaskous, S. and M. W. Pfaffl. 2017. Bioactive properties of minor camel milk ingredients an overview. J. Camel Pract. Res. 24:
$15-26$.

Kattan, J. D., R. R. Cocco and K. M. Järvinen. 2011. Milk and soy allergy. Pediatr. Clin. North Am. 58: 407-426.

Katz, Y., N. Rajuan, M. R. Goldberg, E. Eisenberg, E. Heyman, M. Cohen and M. Leshno. 2010. Early exposure to cow's milk protein is protective against IgE- mediated cow's milk protein allergy. J. Allergy Clin. Immunol. 126: 77-82.e1.

Kleber, N., I. Krause, S. Illgner and J. Hinrichs. 2004. The antigenic response of $\beta$-lg is modulated by thermally induced aggregation. Eur. Food Res. Technol. 219: 105-110.

Koletzko, S., B. Niggemann, A. Arato, J. A. Dias, R. Heuschkel, S. Husby, M. L. Mearin, A. Papadopoulou, F. M. Ruemmele, A. Staiano, M. G. Schäppi and Y. Vandenplas. 2012. European society of pediatric gastroenterology, hepatology, and nutrition. diagnostic approach and management of cow's-milk protein allergy in infants and children. J. Pediatr. Gastroenterol. Nutr. 55: 221-229.

Krömker, V. 2007. Milch als Lebensmittel. In: Kurzes Lehrbuch Michkunde und Milchhygiene. Parey in MVS Medizinverlage Stuutgart, Deutschland, pp. 204-207.

Krüttli, A., A. Bouwman, G. Akgül, P. D. Casa, F. Rühli and C. Warinner. 2014. Ancient DNA analysis reveals high frequency of European lactase persistence allele (T-13910) in medieval central Europe. PLoS One. 9: e86251.

Lack, G. 2008. Epidemiology risks for food allergy. J. Allergy Clin. Immunol. 121: 1331-1336.

Ledl, F. and E. Schleicher. 1990. New aspects of the Maillard reaction in foods and in the human body. Angew. Chem. Int. 29: 565-594.

Leonardi, M., P. Gerbault, M.G. Thomas and J. Burger. 2012. The evolution of lactase persistence in Europe. A synthesis of archaeological and genetic evidence. Int. Dairy J. 22: 88-97.

Lifschitz, C. and H. Szajewska. 2015. Cow's milk allergy: Evidencebased diagnosis and management for the practitioner. Eur $\mathrm{J}$ Pediatr. 74: 141-150.

Maier, I., M. V. Okun, F. Pittner and W. Lindner. 2006. Changes in peptic digestibility of bovine $\beta$-lactoglobulin as a result of food processing studied by capillary electrophoresis and immunochemical methods. J. Chromatogr. B. 841: 160-167.

Majamaa, H., A. Miettinen, S. Laine and E. Isolauri. 1996. Intestinal inflammation in children with atopic eczema: Faecal eosinophil cationic protein and tumour necrosis factor- $\alpha$ as non-invasive indicators of food allergy. Clin. Exp. Allergy. 26: 181-187.

Martorell-Aragones, A., L. Echeverria-Zudaire, E. Alonso-Lebrero, J. Bone-Calvo, M. F. Martin-Munoz, S. Nevot-Falco, M. PiquerGibert and L. Valdesoiro-Navarrete. 2015. Position document: IgE-mediated cow's milk allergy. Allergol. ET immunopathol. 43: 507-526

Mastrorilli, C., C. Caffarelli and K. Hoffmann-Sommergruber. 2017. Food allergy and atopic dermatitis: Prediction, progression, and prevention. Pediatr. Allergy Immunol. 28: 831-840.

Mastrorilli, C., A. Santoro and C. Caffarelli. 2020. Primary prevention of allergic diseases: The role of early exposure to cow's milk formula. Front. Pediatr. 8: 420-426.

Maynard, F., R. Jost, J. M. Wal. 1997. Human IgE binding capacity of tryptic peptides from bovine $\alpha$-lactalbumin. Int. Arch. Allergy Immunol. 113: 478-488.

Maynard, F., A. Weingand, J. Hau, R. Jost. 1998. Effect of high pressure treatment on the tryptic hydrolysis of bovine $\beta$-lactoglobulin $A B$. Int. Dairy J. 8: 125-133.

McGee, H. 2004. Milk and dairy products. In: On Food and Cooking: The Science and Lore of the Kitchen. $2^{\text {nd }}$ ed. Scribner, New York, pp. 7-67. 
Michaelsen, K. F., A. L. H. Nielsen, N. Roos, H. Friis and C. Malgaard. 2011. Cow's milk in treatment of moderate and severe under nutrition in low-income countries. Nestle Nutr. Workshop Ser. Pediatr. Program. 67: 99-111.

Monaci, L., V. Tregoat, A. J. van Hengel and E. Anklam. 2006. Milk allergens, their characteristics and their detection in food: $A$ review. Eur. J. Food Res. Technol. 223: 149-179.

Moorman, P. G. and P. D. Terry. 2004. Consumption of dairy products and the risk of breast cancer: A review of the literature. Am. J. Clin. Nutr. 80: 5-14.

Muehlhoff, E., A. Bennett and D. McMahon 2013. Milk and Dairy Products in Human Nutrition. Food and Agriculture Organization of the United Nations, Rome, pp. 154-182.

O'Keefe, E. S. 1953. The history of infants feeding I. Seventeenth and eighteenth centuries. Arch. Dis. Child. 28: 232-240.

Paige, D. M. 2013. Lactose intolerance. In: Encyclopedia of Human Nutrition. $3^{\text {rd }}$ ed. pp. 67-73.

Park Y., M. F. Leitzmann, A. F. Subar, A. Hollenbeck and A. Schatzkin. 2009. Dairy food, calcium, and risk of cancer in the NIH-AARP diet and health study. Arch. Intern. Med. 169: 391-401.

Parodi, P. W. 2005. Dairy product consumption and the risk of breast cancer. J. Am. Coll. Nutr. 24: 556s-568s.

Parodi, P. W. 2009. Dairy product consumption and the risk of prostate cancer. Int. Dairy J. 19: 551-565.

Pelto, L., O. Impivaara, S. Salminen, T. Poussa, R. Seppanen and E. M. Lilius. 1999. Milk hypersensitivity in young adults. Eur. J. Clin. Nutr. 53: 620-624.

Ran-Ressler, R. R., S. E. Bae, P. Lawrence, D. H. Wang and J. T. Brenna. 2014. Branched chain fatty acid (BCFA) content of foods and estimated intake in the United States. Br. J. Nutr. 112: 565-572.

Raz, M., Y. Sharon, B. Yerushalmi and R. Birk. 2013. Frequency of LCT-13910C/T and LCT-22018G/A single nucleotide polymorphisms associated with adult-type hypolactasia/lactase persistence among Israelis of different ethnic groups. Gene. 519: 67-70.

Reche, M., C. Pascual, A. Fiandor, I. Polanco, M. Rivero-Urgell, R. Chifre, S. Johnston and M. Martín-Esteban. 2010. The effect of a partially hydrolysed formula based on rice protein in the treatment of infants with cow's milk protein allergy. Pediatr. Allergy Immunol. 21: 577-585.

Report. 2014. Ernährungsphysiologische Bewertung von Milch und Milchprodukten und ihren Inhaltsstoffen. Bericht für das Kompetenzzentrum für Ernährung, Bayern. MRI MaxRubner-Institut Bundesfroschungsinstitut für Ernährung und Lebensmittel November, pp. 1-47.

Saarinen, K. M., K. Juntunen-Backman, A. L. Järvinen, P. Kuitunen, L. Lope, M. Renlund and M. Siivola. 1999. Supplementary feeding in maternity hospitals and the risk of cow's milk allergy: A prospective study of 6209 infants. J. Allergy Clin. Immunol. 104: 457-461.

Sakai, K., K. Yoshino, M. A. Satter, F. Ota, Y. Nii, K. Fukuta, N. Ueda, Y. Shimizu and S. Yamamoto. 2000. Effect of $\mathrm{pH}$ variation and $\mathrm{NaCl}$ on in vitro digestibility of cow's milk proteins in commercially available infant formulas. J. Nutr. Sci. Vitaminol. 46: 325-328.

Sampson, H. A. 1999. Food allergy. Part1: Immunopathogenesis and clinical disorders. J. Allergy Clin. Immunol. 103: 717-728.

Sampson, H. A., P. A. Eigenmann, S. H. Sicherer, T. A. Borkowski and B. A. Cohen. 1998. Prevalence of IgE-mediated food allergy among children with atopic dermatitis. Pediatrics. 101: e8.

Santoro, A., L. Andreozzi, G. Ricci, C. Mastrorilli and C. Caffarelli. 2019. Allergic reactions to cow's milk proteins in medications in childhood. Acta Biomed. 90: 91-93.

Savilahti, E. 1981. Cow's milk allergy. Allergy. 36: 73-88.

Schleicher, E. 1991. Die Bedeutung der maillard-reaktion in der menschlichen physiologie. Z. Ernährungswiss. 30: 18-28.

Schlossmann, A. and E. Moro. 1903. München Medizin Wochenschrift. Vol. 14. Springer, Berlin, pp. 597-598.

Schulmeister, U., I. Swoboda, S. Quirce, B. De La Hoz, M. Ollert, G. Pauli, R. Valenta and S. Spitzauer. 2008. Sensitization to human milk. Clin. Exp. Allergy. 38: 60-68.

Selo, I., G. Clement, H. Bernard, J. M. Chatel, C. Cremion, G. Peltre and J. M. Wal. 1999. Allergy to bovine $\beta$-lactoglobulin: Specificity of human IgE to tryptic peptides. Clin. Exp. Allergy. 29: 1055-1063.

Shek, L. P. C., L. Bardina, R. Castro, H. A. Sampson and K. Beyer 2005. Humoral and cellular responses to cow milk proteins in patients with milk-induced IgE-mediated and non-lgE-mediated disorders. Allergy. 60: 912-919.

Shrier I., A. Szilagyi and J. A. Correa. 2008. Impact of lactose containing foods and the genetics of lactase on diseases: An analytical review of population data. NUT Cancer. 60: 292-300.

Skripak, J. M., E. C. Matsui, K. Mudd and R. A. Wood. 2007. The natural history of IgE mediated cow's milk allergy. J. Allergy Clin. Immunol. 120: 1172-1177.

Smits, M. G., T. Huppertz, A. C. Alting and J. Kiers. 2011. Composition, constituents and properties of Dutch camel milk. J. Camel Pract. Res. 18: 1-6.

Song, Y., J. E. Chavarro, Y. Cao, W. Qiu, L. Mucci, H. D. Sesso, M. J. Stampfer, E. Giovannucci, M. Pollak, S. S. Liu and J. J. Ma. 2013. Whole milk intake is associated with prostate cancerspecific mortality among U.S. male physicians. J. Nutr. 143: 189-196.

Stanton, C., D. McMahon and S. Mills. 2013. Dairy components, products and human health. In: E. Muehlhoff, A. Bennett and D. McMahon (Eds.), Milk and Dairy Products in Human Nutrition. Ch. 3. Food and Agriculture Organization of the United Nations, Rome, pp. 207-235.

Szepfalusi, Z., C. Loibichler, J. Pichler, K. Reisenberger, C. Ebner and R. Urbanek. 2000. Direct evidence for transplacental allergen transfer. Pediatr. Res. 48: 404-407.

Szilagyi, A. 2015. Adaptation to lactose in lactase non-persistent people: Effects on intolerance and the relationship between dairy food consumption and evaluation of diseases. Nutrients. 7: 6751-6779.

Szilagyi, A. 2015. Adult lactose digestion status and effects on disease. Can. J. Gastroenterol. Hepatol. 29: 149-156.

Venema, K. 2012. Intestinal fermentation of lactose and prebiotic lactose derivatives, including human milk oligosaccharides. Int. Dairy J. 22: 123-140.

Venter, C. and S. H. Arshad. 2011. Epidemiology of food allergy. Pediatr. Clin. North Am. 58: 327-349.

Venter, C., B. Pereira, J. Grundy, C. B. Clayton, G. Roberts, B. Higgins and T. Dean. 2006. Incidence of parentally reported and clinically diagnosed food hypersensitivity in the first year of life. J. Allergy Clin. Immunol. 117: 1118-1124.

Venter, C., B. Pereira, K. Voigt, J. Grundy, B. C. Clayton, G. Roberts, B. Higgins, S. H. Arshad and T. Dean. 2008. Prevalence and cumulative incidence of food hypersensitivity in the first 3 years of life. Allergy. 63: 354-359.

Vesa, T. H., P. Marteau and R. Korpela. 2000. Lactose intolerance. J. Am. Coll. Nutr. 19: 165s-175s.

Wal, J. M. 1998a. Cow's milk allergens. Allergy. 53: 1013-1022.

Wal, J. M. 1998b. Strategies for assessment and identification of 
allergenicity in (novel) foods. Int. Dairy J. 8: 413-423.

Wal, J. M. 2002. Cow's milk proteins/allergens. Ann. Allergy Asthma Immunol. 89: 3-10.

Weingarten, M. A., A. Zalmanovici and J. Yaphe. 2008. Dietary calcium supplementation for preventing colorectal cancer and adenomatous polyps. Cochrane Database Syst. Rev. 23: 1.

Wernery, U. 2007. Camel Milk-new Observations. Proceedings of the International Camel Conference Recent Trends in Camelids Research and Future Strategies for Saving Camels, Rajasthan, India, 16-17 February 2007, pp. 200-204.

Wernstedt, W. 1910. Monatsschrift Kinderheilkunde. Vol. 9. p. 2526.

Wood, R. A., S. H. Sicherer, B. P. Vickery, S. M. Jones, A. H. Liu, D.
M. Fleischer, A. K. Henning, L. Mayer, A. W. Burks, A. Grishin, D. Stablein and H. A. Sampson. 2013. The natural history of milk allergy in an observational cohort. J. Allergy Clin. Immunol. 131: 805-8012.

Wroblewska, B. and L. Jedrychowski 1994. Detection and determination of $\alpha$ - lactalbumin in milk using enzyme-linked immunosorbent assay (ELISA). Pol. J. Food Nutr. Sci. 3: 45-53.

www.nhs.uk. 2019. Diagnosis-Food Allergy. http://www.nhs.uk.

www.quarks.de. 2020. Milch: Macht sie Uns Krank?-quarks.de. http:// www.quarks.de.

www.utopia.de. 2015. Ist Milch Gesund? 5 Argumente Gegen Milch. http://www.utopia.de. 